\title{
Managed and unmanaged silver fir-beech forests show similar structural features in the western Pyrenees
}

\author{
Vlatka Horvat, \\ Jorge García De Vicuña, \\ Idoia Biurrun, \\ Itziar García-Mijangos
}

\begin{abstract}
Forest structure is considered one of the basic features of the forest ecosystem and it is widely studied with the aim of developing sustainable management strategies. The usual approach is to compare structural features of stands in managed and unmanaged forests. Managed stands are those disturbed in some way by silvicultural practices, whereas unmanaged stands are subject to natural disturbance dynamics and may serve as a reference. Up to now, there has been insufficient research into sustainable management strategies for Pyrenean silver fir-beech forests and the structure of managed and unmanaged stands has not yet been evaluated. The aim of this study is to provide a detailed characterisation of the structural attributes of these mixed mountain forests in the western Pyrenees and compare managed and unmanaged stands regarding selected stand parameters. Potential differences between managed and unmanaged stands were assessed with Mann-Whitney Utests. Diameter distribution was modelled using third-order polynomials and non-linear regression was performed to compare the tree heights in managed and unmanaged stands. Stand structure was similar in both management categories. The diameter distribution of Pyrenean unmanaged silver fir-beech stands showed a tendency towards a rotated sigmoid distribution. Our results indicate that the recommended diameter distribution has been preserved in managed stands despite they were intensively managed in the past, whilst the unmanaged stands are still in the process of developing old-growth attributes because management was abandoned too recently for significant changes in forest structure to have occurred.
\end{abstract}

\section{Keywords: Forest Management, Gaps, Pyrenees, Stand Structure}

in the forest canopy and changing the light regime. Creation of gaps initiates regeneration processes in the understory, thus affecting stand dynamics (Yamamoto 2000). The understory microclimate is also dependent on canopy structure, particularly canopy density (Arx et al. 2012). Moreover, forest structure may influence edaphic factors such as soil water content, $\mathrm{pH}$, temperature and nutrient availability (Barbier et al. 2008). Because forest structure strongly influences environmental conditions in the understory it has been considered a key determinant of biodiversity patterns in forest ecosystems (Gao et al. 2014). To assess how management affects stand structure one must estimate stand parameters such
Dept. Plant Biology and Ecology, University of the Basque Country UPV/EHU, P. O. Box 644, Bilbao (Spain)

@ Vlatka Horvat (vlatkahorvat0@gmail.com)

Received: Jan 03, 2018 - Accepted: Jul 26, 2018

Citation: Horvat V, García De Vicuña J, Biurrun I, García-Mijangos I (2018). Managed and unmanaged silver fir-beech forests show similar structural features in the western Pyrenees. iForest 11: 698-704. - doi: 10.3832/ifor2720-011 [online 2018-10-23]

Communicated by: Gianluca Piovesan as the distribution of diameters, tree density, tree height, canopy closure and the quantity of dead wood. In view of the importance of forest structure, modern forestry strives to balance economic and ecological needs through appropriate management methods.

The concept of sustainable forest management is based on the emulation of natural processes, which can be studied in unmanaged forests. Unmanaged forests provide valuable information for developing management strategies and effective conservation policies because their dynamics has not been affected by human intervention (Burrascano et al. 2013), whereas in managed forests the natural processes have been disturbed in some way, with the intensity of the disturbance depending on the management strategy applied.

Forest structure has been evaluated in many managed and unmanaged European forests (Boncina 2000, Bianchi et al. 2011, Bilek et al. 2011, Sitzia et al. 2012, Schütz et al. 2016), but there is a dearth of information about Pyrenean forests (Gil Pelegrín et al. 1989). Forests dominated by silver fir (Abies alba Mill.) and European beech (Fagus sylvatica L.) in the Pyrenees have been managed over the centuries, but their management history is not completely clear as documentation of silvicultural practices is 
scant. The available management history for the region (Gobierno de Navarra 2000) suggests that most of the western Pyrenean forests were over-exploited at the beginning of the $20^{\text {th }}$ century, either through timber exploitation or grazing. There were frequent changes in the approach to managing these mixed stands, with selection systems, shelterwood, clearcuts or exclusive silver fir logging all being applied at some point. In the last 50 years human migration and the abandonment of these activities have led to increases in forest cover and growing stock (Gobierno de Navarra 2000). At present, most of the forests in the western Pyrenees are subjected to regular management, which promotes sustainable forest management (Gobierno de $\mathrm{Na}$ varra 2000), the exceptions are areas within natural parks or strict reserves, which remain unmanaged.

In the context of forest management in the Pyrenees, the present study aims to provide for the first time a detailed characterisation of the structural attributes of these mixed mountain forests and to compare managed and unmanaged stands regarding selected stand parameters. We hypothesised that stand structure would differ between actively managed stands and well-preserved remnants never subjected to intensive forest management and withdrawn from the management plans 40 years ago.

\section{Material and methods}

\section{Study area}

The study area is located in the western part of the Pyrenees, specifically in the Spanish part of the massif, which encompasses the regions of Navarre and Aragon (Fig. 1). The landscape is characterised by valleys and mountains stretching from west to east and ranging in elevation from 1800 to $2500 \mathrm{~m}$ a.s.l. The bedrock is limestone and marly flysch, with brown soils. Biogeographically the area belongs to the Alpine region and according to the Global Bioclimatic Classification System developed by Rivas-Martínez (2007), the biocli- mate is temperate oceanic, with a mean annual temperature of $8^{\circ} \mathrm{C}$, mean annual rainfall of $1419 \mathrm{~mm}$ and a W-E continentality gradient. A long history of livestock and forest exploitation has shaped the landscape in this area, which is highly heterogeneous and, in the beech belt, contains semi-natural grasslands, scrublands, natural forests and Pinus sylvestris L. plantations. Silver fir reaches its southwestern distribution limit in the western Pyrenean beech belt, growing in mixed stands together with beech and even dominating in some stands. The silver fir-beech forests of the study area are included in the association Scillo lilio-hyacinthi-Fagetum sylvaticae Br.-Bl. ex O. Bolòs 1957, which encompasses ombrophilous hyper-humid forests (Rivas-Martínez et al. 1991). The management history of these stands is unclear because silvicultural practices during the last century were unsystematic and varied in intensity. According to the Forest Management Plan of Navarre (Gobierno de Navarra 2000) a great variety of management approaches have been recorded (single and group selection systems, shelterwood and exclusive fir exploitation). The westernmost stands were intensively managed in the past and currently they are subjected to regular forest management, whereas the easternmost stands have mostly been abandoned for at least 40 years, have never been intensively managed and lie within natural parks and strict reserves.

\section{Sampling design}

We identified all north-facing stands of silver fir-beech forests exceeding 30 ha, between 800 and $1700 \mathrm{~m}$ a.s.l. Twenty stands encompassing a total of approximately 700 ha fulfilled these criteria. We defined managed stands as those managed between 5 and 20 years ago and unmanaged stands as those where no regular management occurs and timber has not been harvested for at least 40 years. The rarity of well-preserved forests in the western Pyrenees meant we were only able to sample four unmanaged stands. To provide a balanced sampling we also selected four managed stands with similar site conditions. Four plots were randomly sampled in each stand (see Tab. S1 in Supplementary material). This resulted in a total of 32 plots grouped into eight clusters (Fig. 1). Field sampling was carried out in 2015 under permits from the Government of Navarre and Aragon.

Stand structure sampling (Tab. 1) was based on measuring diameter-at-breastheight (DBH) for all trees within three concentric circles with radii of 4,13 and $20 \mathrm{~m}$. We recorded all standing trees (living and dead) that exceeded a pre-established DBH threshold in each circle: $2.5 \mathrm{~cm}$ for the 4-m radius circle, $10 \mathrm{~cm}$ for the $13-\mathrm{m}$ radius circle and $50 \mathrm{~cm}$ for the 20-m radius circle. For the dead standing trees, we used the term "snags". Deadwood was quantified by measuring the diameter of all the lying dead wood components (logs) of diameter $\geq 10 \mathrm{~cm}$ within the $13-\mathrm{m}$ radius circle. We classified the decay stage of logs according to Hunter's (1990) framework, which distinguishes five decay classes ranging from freshly fallen (decay class 1 ) to heavily decomposed (decay class 5). The tree heights were measured with the Haglof Vertex hypsometer for five individuals out of those whose DBH was measured, in total 160 trees randomly chosen within the sampled stands. Living wood volume was not calculated due to the lack of volume tables for this area.

We distinguished four diameter categories in living trees: very large trees (DBH $\geq 67.5 \mathrm{~cm})$, large trees $(47.5 \leq \mathrm{DBH}<67.5$ $\mathrm{cm})$, medium trees $(22.5 \leq \mathrm{DBH}<47.5 \mathrm{~cm})$ and small trees $(7.5 \leq \mathrm{DBH}<22.5 \mathrm{~cm})$. The structural diversity of each plot was expressed as the coefficient of diameter variation (CV_DBH - Tab. 1).

We evaluated stand structure using the LikeJ index (Hanewinkel et al. 2014), which describes how closely the diameter distribution approximates a J-shape. This index is based on the number of stems per hectare in different diameter classes; the maximum value of closeness to the inverse $J$ shape is 10 (Hanewinkel et al. 2014). Traditionally the inverse J-shaped distribution has been regarded as the desirable distri-

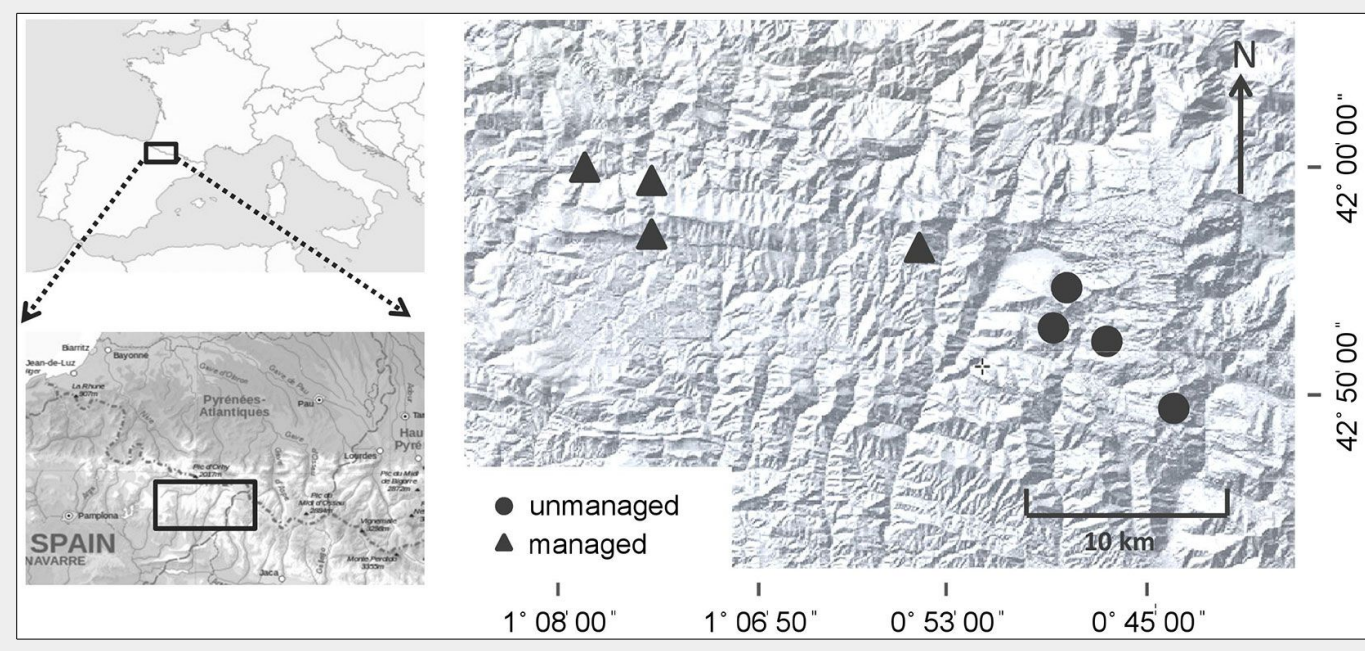

Fig. 1 - Study area and location of the eight sampled stands in the western Pyrenees, N Spain. 
Tab. 1 - Topographic, stand structural and light condition variables for 32 plots used in the comparison of managed and unmanaged stands in the western Pyrenean silver fir-beech forests. Differences between managed and unmanaged plots were tested using Mann-Whitney's U test. (Gaps): percentage of large gaps; (CV_DBH): coefficient of diameter variation; $(*): p<0.05 ;(* *): p<0.01$; $(* * *): p<0.001$

\begin{tabular}{|c|c|c|c|c|c|}
\hline \multirow{2}{*}{ Group } & \multirow{2}{*}{ Variables } & \multirow{2}{*}{ Units } & \multicolumn{2}{|l|}{ Mean \pm SD } & \multirow{2}{*}{$p$ value } \\
\hline & & & Managed & Unmanaged & \\
\hline \multirow[t]{2}{*}{ Topography } & Elevation & m a.s.l. & $1118 \pm 104.70$ & $1447 \pm 140.76$ & $<0.001^{* * *}$ \\
\hline & Slope & $\%$ & $46.62 \pm 16.21$ & $39.19 \pm 12.40$ & 0.19 \\
\hline \multirow[t]{2}{*}{ Light conditions } & Transmission & $\%$ & $10.81 \pm 6.13$ & $11.20 \pm 2.67$ & 0.36 \\
\hline & Gaps & $\%$ & $6.70 \pm 5.50$ & $5.9 \pm 2.28$ & 0.89 \\
\hline \multirow[t]{18}{*}{ Stand structure } & Tree density & $\mathrm{N}$ ha $^{-1}$ & $638 \pm 286$ & $806 \pm 617$ & 0.83 \\
\hline & Beech density & $\mathrm{N}$ ha $^{-1}$ & $517 \pm 389$ & $783 \pm 650$ & 0.25 \\
\hline & Fir density & $\mathrm{N}$ ha $^{-1}$ & $188 \pm 130$ & $111 \pm 16$ & $0.03^{*}$ \\
\hline & Density of small trees & $\mathrm{N}$ ha $^{-1}$ & $11.25 \pm 8.31$ & $13.56 \pm 10.22$ & 0.52 \\
\hline & Density of medium trees & $\mathrm{N}$ ha $^{-1}$ & $10.43 \pm 5.42$ & $7.18 \pm 4.57$ & 0.07 \\
\hline & Density of large trees & $\mathrm{N}$ ha $^{-1}$ & $5.00 \pm 2.50$ & $4.43 \pm 2.03$ & 0.30 \\
\hline & Density of very large trees & $\mathrm{N}$ ha $^{-1}$ & $0.75 \pm 0.93$ & $1.93 \pm 1.94$ & 0.09 \\
\hline & Density of very large fir trees & $\mathrm{N}$ ha $^{-1}$ & $3.97 \pm 5.81$ & $12.43 \pm 15.90$ & 0.20 \\
\hline & Density of very large beech trees & $\mathrm{N}$ ha $^{-1}$ & $1.98 \pm 6.16$ & $2.98 \pm 5.71$ & 0.42 \\
\hline & Basal area of living trees & $\mathrm{m}^{2} \mathrm{ha}^{-1}$ & $34.95 \pm 9.41$ & $35.20 \pm 12.61$ & 0.79 \\
\hline & Basal area of beech & $\mathrm{m}^{2} \mathrm{ha}^{-1}$ & $21.66 \pm 7.89$ & $22.93 \pm 9.31$ & 0.53 \\
\hline & Basal area of fir & $\mathrm{m}^{2} \mathrm{ha}^{-1}$ & $14.37 \pm 11.06$ & $14.51 \pm 17.13$ & 0.44 \\
\hline & Basal area of snags & $\mathrm{m}^{2} \mathrm{ha}^{-1}$ & $1.21 \pm 2.47$ & $2.27 \pm 2.70$ & 0.08 \\
\hline & Basal area of logs & $\mathrm{m}^{2} \mathrm{ha}^{-1}$ & $3.89 \pm 3.91$ & $2.21 \pm 1.80$ & 0.46 \\
\hline & Basal area of total dead wood & $\mathrm{m}^{2} \mathrm{ha}^{-1}$ & $5.09 \pm 4.18$ & $4.53 \pm 2.77$ & 0.95 \\
\hline & Number of stumps & $\mathrm{N}_{\text {plot }}{ }^{-1}$ & $3.68 \pm 2.86$ & $2.18 \pm 3.63$ & 0.05 \\
\hline & CV_DBH & - & $50.40 \pm 18.23$ & $62.36 \pm 17.77$ & 0.06 \\
\hline & LikeJ index & - & $6.05 \pm 2.05$ & $4.95 \pm 1.68$ & 0.10 \\
\hline
\end{tabular}

bution for diameter in managed forests showing heterogeneity in age (O'Hara \& Gersonde 2004), but old-growth forests, which could serve as a model, show a variety of diameter distributions (Westphal et al. 2006).

Light condition variables (Tab. 1) were obtained by hemispherical photography. A detailed light sampling and analysis protocol is provided in Appendix 1 (Supplementary material). We calculated the following variables: "transmission", a measure of overall canopy openness or total gap fraction, and "gaps", the proportion of large between-crown gaps.

\section{Data analysis}

The structural features of managed and unmanaged stands are represented in figures and tables compiled to make data visualisation. Differences between the management categories with respect to selected stand parameters and topographic variables were assessed with Mann-Whitney U-tests (Tab. 1). Diameter distribution was modelled using third-order polynomials where tree density was converted to a logarithmic scale. Non-linear regression was performed to compare the tree heights in managed and unmanaged stands as this permits tree height to be predicted from observed DBH. The regression was fitted using the power equation $h=a(\mathrm{DBH})^{\mathrm{b}}$ (Huang et al. 1992), where $h$ is the tree height and $a$ and $b$ are estimated parameters.

\section{Results}

The tree layer was dominated by European beech (Fagus sylvatica), followed by silver fir (Abies alba), whilst the tree species Acer opalus Mill., Sorbus aucuparia L., Salix caprea L. and Tilia platyphyllos Scop. were recorded as saplings (Horvat et al. 2017). "Transmission" and "gaps" were highly correlated. Average transmission was $11.1 \%$, and the mean percentage of large gaps was $6.3 \%$, so large gaps accounted for more than half of the canopy

openness. The percentage of large gaps was similar $(p>0.05)$ in managed and unmanaged stands (Tab. 1).

The per-hectare basal area of living trees was similar $(p>0.05)$ in managed and unmanaged stands (Tab. 1), as well as the total basal area of small, medium, large and very large trees (results not shown). However, trees in the diameter classes over 85 $\mathrm{cm}$ were absent from managed stands (Fig. 2). Like mean basal area, total tree density and densities of small, medium, large and

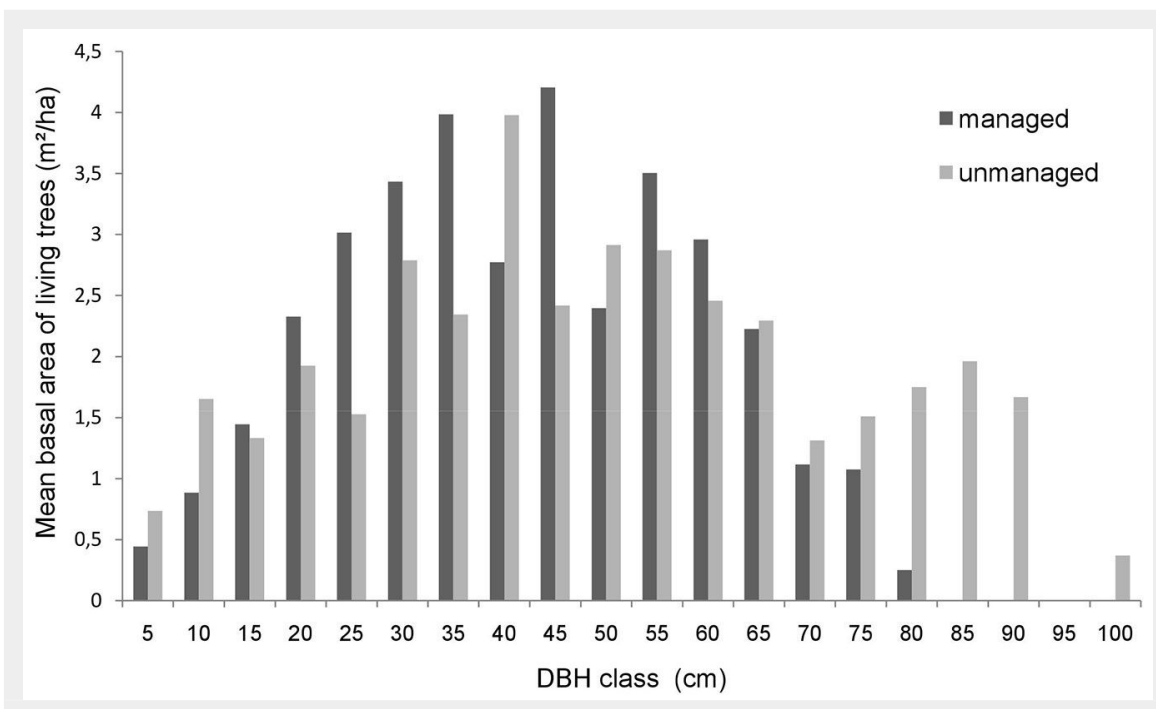

Fig. 2 - Distribution of basal area of living trees by DBH classes in managed and unmanaged stands of silver fir-beech forests in the western Pyrenees. 
Fig. 3 - Diameter distribution modeled using a thirdorder polynomial in the managed and unmanaged stands of silver firbeech forests in the western Pyrenees.

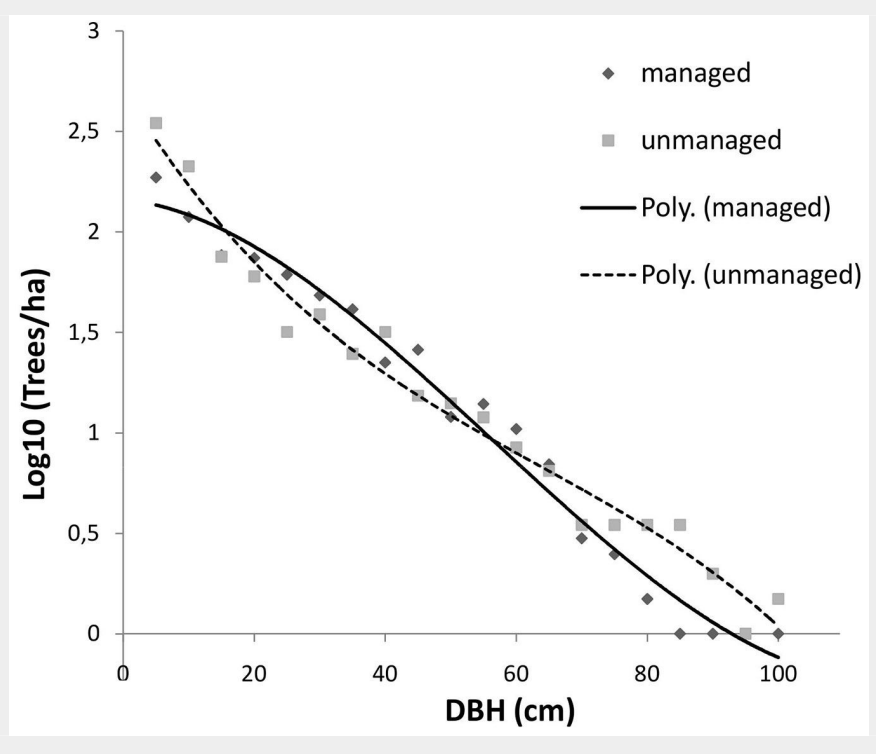

(a)
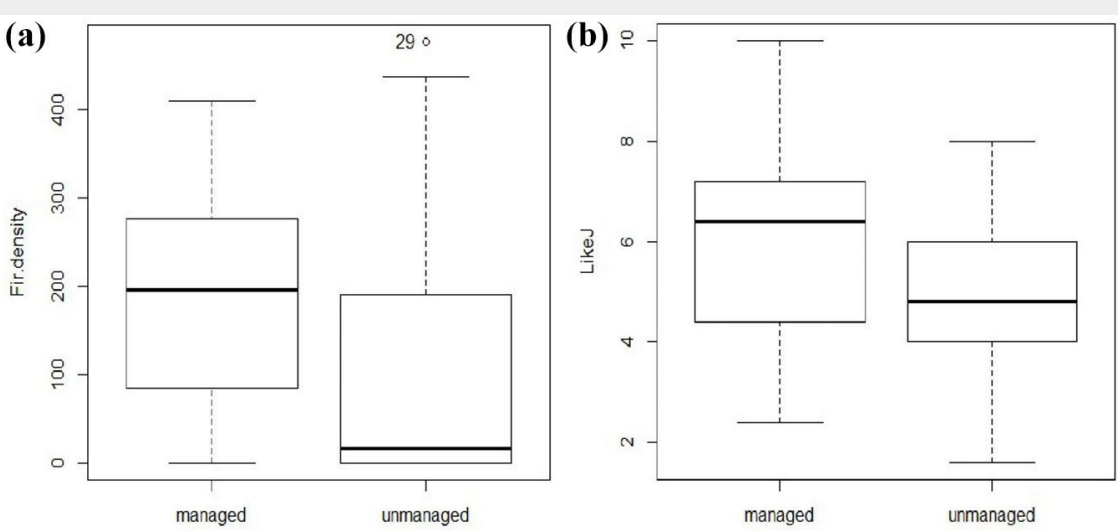

Fig. 4 - (a) Boxplot of fir density per hectare in managed and unmanaged stands of silver fir-beech forests in the western Pyrenees. Fir density was significantly higher in managed stands than in unmanaged ones $(p<0.05)$. (b) Boxplot of LikeJ index, closeness to an inverse $J$ shape, in the managed and unmanaged silver fir-beech stands from the western Pyrenees. Regarding the LikeJ index, managed and unmanaged stands did not differ significantly ( $p>0.05)$. Maximum value of LikeJ index is 10 , describing desirable forest structure for uneven-aged managed forests.

very large trees were similar in both management categories ( $p>0.05-$ Tab. 1, Fig. 3 ), however unmanaged stands tended to have higher density of small and very large trees (Fig. 3). Separate analyses of individual species revealed that beech density was similar in managed and unmanaged stands $(p>0.05)$, but the density of silver fir was greater in the managed stands $(p<$ 0.05 - Tab. 1, Fig. 4a). In sampled stands

the LikeJ index varied from 1.6 to 10 and was similar in managed and unmanaged stands $(p>0.05)$, although in absolute terms unmanaged stands tended to have lower LikeJ values (Fig. 4b).

The total basal area of dead wood was similar in managed and unmanaged stands (Tab. 1). Decay class 2 was the most frequent in all stands and decay class 5 was absent from unmanaged stands (Tab. 2).

Tab. 2 - Percentage of dead wood across the decay classes in managed and unmanaged stands in silver fir-beech forests in the western Pyrenees.

\begin{tabular}{ccc}
\hline \multirow{2}{*}{ Decay class } & \multicolumn{2}{c}{ \% of total dead wood per plot } \\
\cline { 2 - 3 } & Managed & Unmanaged \\
\hline 1 & 24.10 & 33.33 \\
2 & 34.94 & 43.94 \\
3 & 22.89 & 19.70 \\
4 & 15.66 & 3.03 \\
5 & 2.41 & 0 \\
\hline
\end{tabular}

There were no differences in the heightdiameter curves for beech between both management types (Fig. 5). However, the model showed a low fit $\left(R^{2}=0.33\right.$ and $R^{2}=$ 0.41 for managed and unmanaged stands, respectively) because of the height variability within DBH classes. The silver fir height model had a better fit in both managed and unmanaged stands $\left(R^{2}=0.71, R^{2}=\right.$ 0.83 ) and slightly different curves were obtained for both categories. Silver fir of DBH $=60 \mathrm{~cm}$ reached a greater height in managed stands than in unmanaged stands (Fig. 5).

\section{Discussion}

Mean values for canopy openness were low (approximately 10\%) in both the managed and unmanaged Pyrenean forests studied, suggesting a rather closed canopy. The gap fraction values in the sampled forests were within the range of values reported for unmanaged stands in Central Europe, where gap fraction varies between 3 and 16\% (Kucbel et al. 2010). The low gap fraction and the small size of the gaps suggest that unmanaged Pyrenean forests follow a pattern of small-scale disturbance, which has also been found in other wellpreserved beech forests (Rugani et al. 2013, Hobi et al. 2015). In the case of managed Pyrenean stands the low gap fraction and small gap size (never exceeding 400 $\mathrm{m}^{2}$ - Horvat et al. 2017) suggest that management is not intensive and emulates natural forest dynamics. However, point data on gap fraction only provide a static picture of the status of a forest (Kenderes et al. 2008), so further research on gap dynamics is needed to draw firm conclusions.

Compared with European old-growth forests (Burrascano et al. 2013), the unmanaged stands of the studied Pyrenean forests showed a lower mean basal area per hectare, which we attribute to the short period of forest abandonment. These unmanaged stands are located at the highest elevations, following a spatial pattern already reported in the Apennines (Piovesan et al. 2005), where low soil productivity and unfavourable climatic conditions could potentially affect tree growth and basal area (Burrascano et al. 2013). However, evidence for our conclusion that forest management has a greater negative effect on basal area than elevation comes from the presence of large fir trees at the highest elevations (1600 m a.s.l.) of the Aztaparreta old-growth forest.

Although we did not find differences in basal area between both management categories, we did observe a shift towards larger diameter classes $(>80 \mathrm{~cm})$ in unmanaged stands, which could be a consequence of management cessation.

Tree density was similar in managed and unmanaged stands for the categories of small, medium, large and very large trees. However, the diameter distribution varied slightly with management category. The main difference observed was that unman- 
Fig. 5 - Height-diameter models of beech and silver fir for managed and unmanaged stands in the western Pyrenees. The equation for the beech trees in the managed stands is $h=8.3 \times \mathrm{DBH}^{0.287}$, with $\mathrm{R}^{2}=0.33$; for unmanaged stands, $h=6.973 \times$ $\mathrm{DBH}^{0.332}$, with $\mathrm{R}^{2}=0.41$. The equation for the fir trees in the managed stands is $h=$ $2.5 \times \mathrm{DBH}^{0.666}$ with $\mathrm{R}^{2}=0.71$; for unmanaged stands, $h=$ $4.17 \times \mathrm{DBH}^{0.444}$, with $\mathrm{R}^{2}=$ 0.83 .
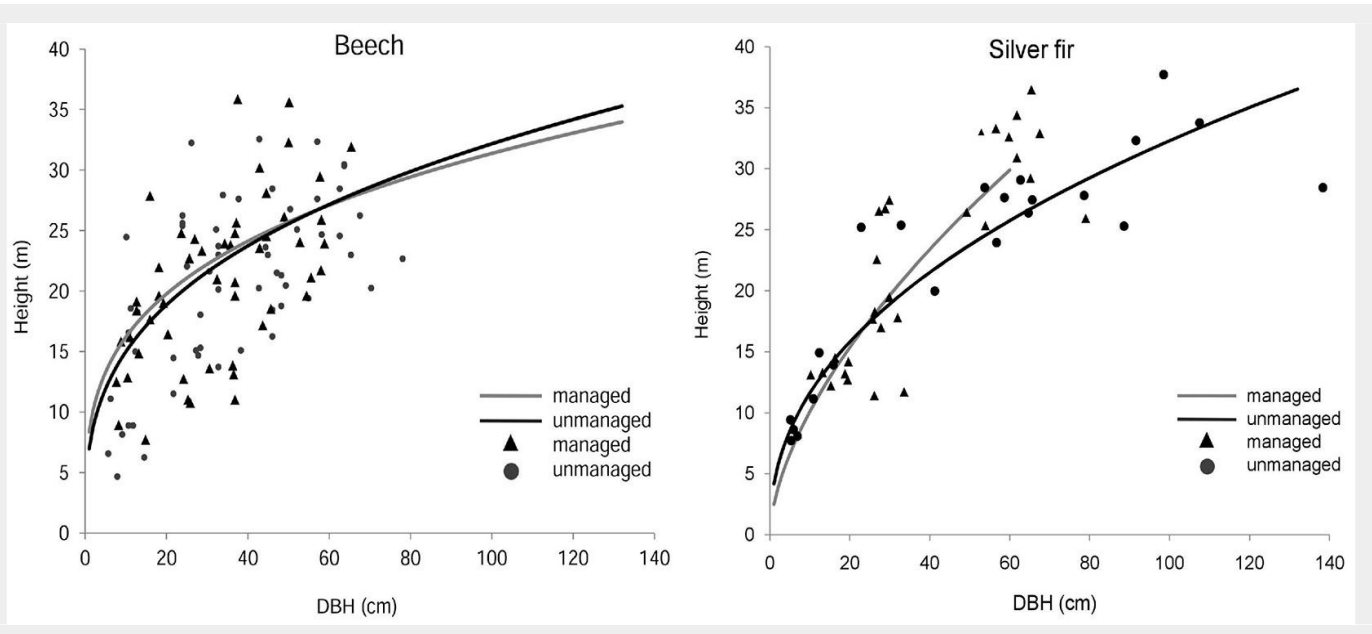

aged stands tended to have a higher density of very small trees, as a consequence of natural regeneration and lack of management practices, as well as a higher density of the largest trees due to management cessation. Having a high density of small and large trees, the diameter distribution of unmanaged stands showed tendency to a rotated-sigmoid curve, which is one of the known distribution of oldgrowth forests (Schwartz et al. 2005, Westphal et al. 2006).

The minimum value of the LikeJ index was measured in the old-growth forest Aztaparreta, where natural dynamics prevail and in which biomass is accumulated in the largest DBH classes. Medium LikeJ values in the managed forests may reflect the mixture of management approaches used in these forests. Assuming that forest sustainability can be evaluated by diameter distribution (Rubin et al. 2006), Pyrenean forests can be considered relatively stable systems, with unmanaged forests being in the recovery stage after the abandonment of past management practices.

The greater density of silver firs in the managed stands may be a consequence of recent forest management practices that favour silver fir. Since silver fir decline has been confirmed in this area (Oliva \& Colinas 2007), forest managers have adapted their management practices in order to preserve this species (Gobierno de Navarra 2000). Lower fir density in the unmanaged stands may indicate that silver fir does not regenerate well, perhaps due to the dominance of beech (Dobrowolska 1998), although the reasons for the lack of fir regeneration remains an open question (Oliva \& Colinas 2007).

The height-diameter model for beech showed great height dispersion across the diameter classes, indicating that the beech trees of similar diameter had very different heights. This observation could be because beech is a shade-tolerant species, with saplings of up to 35 years (Collet et al. 2008). Tree height increases slowly in these multilayered stands, where light levels are low, but when the canopy opens saplings take advantage and their height increases rapidly (Nagel \& Diaci 2006, Rugani et al. 2013). Similar findings have been reported for beech forests where trees in the upper storey were $22 \mathrm{~m}$ high and varied widely in diameter, from 20 to $100 \mathrm{~cm}$ (Commarmot et al. 2005, Rugani et al. 2013).

With respect to the fir height-diameter model, firs in the $60 \mathrm{~cm}$ DBH class were taller in the managed stands than in the unmanaged ones, probably as a result of current forest management, which removes competition for light, water and nutrients from beech trees, thus favouring fir growth. This interpretation is consistent with the higher fir density found in the managed stands. Tree heights may also depend on site quality; in particular silver fir stand productivity depends on rainfall and temperature, rather than soil properties (Becker 1989, Pinto et al. 2008). Soil properties in the sampled stands were similar with respect to clay percentage, organic matter and nitrogen (Horvat et al., unpublished results), so we have excluded the possibility that these factors affected tree height. The managed and unmanaged stands in our study have similar annual precipitation, although they are spatially clustered, and so water availability should not be a limiting factor. Another feature observed in managed forests was the absence of large fir trees, also a consequence of past forest management, which was oriented towards the logging of large silver firs (Sangüesa-Barreda et al. 2015).

Surprisingly, the total basal area of dead wood did not vary between managed and unmanaged stands, in contrast with the findings of other studies (Motta et al. 2013, Silver et al. 2013). This indicates that forest managers are applying appropriate management strategies, mainly involving retention of a certain quantity of logs and snags to enhance biodiversity. Although fewer stumps were counted in unmanaged stands, differences regarding the number of stumps were not significant between both management categories. This fact confirms that the abandonment of management is relatively recent, given that total decomposition of coarse woody debris from beech takes about 35 years (MüllerUsing \& Bartsch 2009). Nevertheless, more detailed studies on dead wood quantity are needed, as in this study we have used the basal area of dead wood as an approximate index of dead wood quantity.

From the obtained results, we infer that these unmanaged stands are still on the way to become old-growth stands. Management ceased approximately 40 years ago, so these forests have not yet developed clear old-growth attributes, because the recovery of ecosystems after cessation of management is a rather slow process (Barbati et al. 2012, Paillet et al. 2015).

\section{Conclusions}

Our study has analysed the differences in stand structure of managed and unmanaged silver fir-beech forests in the western Pyrenees. The unmanaged forests tend to have fewer stumps, a higher density of small trees and an increased basal area in larger DBH classes, although the managed and unmanaged forests have a similar structure. These unmanaged stands are still on the way to become old-growth stands whilst managed forests, which showed a high variation in tree diameter, are under sustainable management practices. Silvicultural practices should focus on the preservation of the natural proportions of fir and beech, although the observed decline in silver fir provides a rationale for management strategies that favour this species.

\section{List of abbreviations}

DBH: diameter-at-breast-height; CV_DBH: coefficient of diameter variation.

\section{Acknowledgements}

VH and JGV performed the field measurements. VH performed the statistical analysis and led the writing, and IB and IGM contributed to the study design and revision of manuscript. We thank Almudena Pereda and Raul Ilundain for help with field work and Francesco Sabatini and Sabina Burrascano for assistance with the sampling protocol. Funds from the project IT299-10 for research groups of the Basque Govern- 
ment were used for this study.

\section{References}

Arx G, Dobbertin M, Rebetez M (2012). Spatiotemporal effects of forest canopy on understory microclimate in a long-term experiment in Switzerland. Agricultural and Forest Meteorology 166-167: 144-155. - doi: 10.1016/j.agrformet. 2012.07.018

Barbati A, Salvati R, Ferrari B, Di Santo D, Quatrini A, Portoghesi L, Travaglini D, lovino F, Nocentini S (2012). Assessing and promoting oldgrowthness of forest stands: Lessons from research in Italy. Plant Biosystems 146: 167-174. doi: 10.1080/11263504.2011.650730

Barbier S, Gosselin F, Balandier P (2008). Influence of tree species on understory vegetation diversity and mechanisms involved-a critical review for temperate and boreal forests. Forest Ecology and Management 254: 1-15. - doi: 10.1016/j.foreco.2007.09.038

Becker M (1989). The role of climate on present and past vitality of silver fir forests in the Vosges mountains of northeastern France. Canadian Journal of Forest Research 19: 1110-1117. doi: $10.1139 / \times 89-168$

Bianchi L, Bottacci A, Calamini G, Maltoni A, Mariotti B, Quilghini G, Salbitano F, Tani A, Zoccola A, Paci $M$ (2011). Structure and dynamics of a beech forest in a fully protected area in the northern Apennines (Sasso Fratino, Italy). iForest - Biogeosciences and Forestry 4 (3): 136-144. - doi: 10.3832/ifor0564-004

Bilek L, Remes J, Zahradnik D (2011). Managed vs. unmanaged. Structure of beech forest stands (Fagus sylvatica L.) after 50 years of development, Central Bohemia. Forest Systems 20: 122-138. - doi: 10.5424/fs/2011201-10243

Boncina A (2000). Comparison of structure and biodiversity in the Rajhenav virgin forest remnant and managed forest in the Dinaric region of Slovenia. Global Ecology and Biogeography 9: 201-211. - doi: 10.1046/j.1365-2699.2000.0015 $5 . x$

Burrascano S, Keeton WS, Sabatini FM, Blasi C (2013). Commonality and variability in the structural attributes of moist temperate old-growth forests: a global review. Forest Ecology and Management 291: 458-479. - doi: 10.1016/j.for eco.2012.11.020

Collet C, Piboule A, Leroy O, Frochot H (2008). Advance Fagus sylvatica and Acer pseudoplatanus seedlings dominate tree regeneration in a mixed broadleaved former coppice-with-standards forest. Forestry 81: 135-150. - doi: 10.1093/ forestry/cpnoo4

Commarmot B, Bachofen H, Bundziak V, Bürgi A, Ramp B, Shparyk Y, Sukhariuk D, Viter R, Zingg A (2005). Structures of virgin and managed beech forests in Uholka (Ukraine) and Sihlwald (Switzerland): a comparative study. Forest Snow and Landscape Research 79: 45-56. [online] URL: http://www.researchgate.net/publica tion/268261842

Dobrowolska D (1998). Structure of silver fir (Abies alba Mill.) natural regeneration in the Jata' reserve in Poland. Forest Ecology and Management 110: 237-247. - doi: 10.1016/S03781127(98)00286-2

Gao $T$, Hedblom $M$, Emilsson $T$, Nielsen $A B$ (2014). The role of forest stand structure as bio- diversity indicator. Forest Ecology and Management 330: 82-93. - doi: 10.1016/j.foreco.2014.07. 007

Gil Pelegrín E, Villar L, López Unzu F (1989). Sobre la estructura de un hayedo abetal virgen en el Pirineo Occidental: la selva de Aztaparreta (Alto Roncal-Navarra) [On the structure of a virgin silver fir-beech forest in the western Pyrenees: the forest of Aztaparreta (Alto Roncal-Navarre)]. Acta Biologica Montana 9: 225236. [in Spanish]

Hanewinkel M, Kuhn T, Bugmann H, Lanz A, Brang P (2014). Vulnerability of uneven-aged forests to storm damage. Forestry 87: 525-534. - doi: 10.1093/forestry/cpuoo8

Hobi ML, Commarmot B, Bugmann H (2015). Pattern and process in the largest primeval beech forest of Europe (Ukrainian Carpathians). Journal of Vegetation Science 26: 323-336. - doi: 10.1111/jvs.12234

Horvat V, Biurrun I, García-Mijangos I (2017). Herb layer in silver fir-beech forests in the western Pyrenees: does management affect species diversity? Forest Ecology and Management 385: 87-96. - doi: 10.1016/j.foreco.2016.11.037

Huang S, Titus SJ, Wiens DP (1992). Comparison of nonlinear height-diameter functions for major Alberta tree species. Canadian Journal of Forest Research 22: 1297-1304. - doi: 10.1139/x9 2-172

Hunter ML (1990). Wildlife, forests, and forestry. Principles of managing forests for biological diversity. Prentice Hall, Englewood Cliffs, NJ, USA, pp. 370. [online] URL: http://www.cab direct.org/cabdirect/abstract/19910654124

Kenderes K, Mihók B, Standovár T (2008). Thirty years of gap dynamics in a Central European beech forest reserve. Forestry 81: 111-123. - doi: 10.1093/forestry/cpnoo1

Kucbel S, Jaloviar P, Saniga M, Vencurik J, Klimaš $\checkmark$ (2010). Canopy gaps in an old-growth firbeech forest remnant of Western Carpathians. European Journal of Forest Research 129: 249259. - doi: 10.1007/s10342-009-0322-2

Motta R, Berretti R, Borchi S, Bresciani A, Garbarino $M$, Trucchi $D$ (2013). Stand structure and coarse woody debris profile of "La Verna" forest (Arezzo, Italy). Italian Journal of Forest and Mountain Environments 65: 591-605. [online] URL: http://ojs.aisf.it/index.php/ifm/article/view 1438

Müller-Using S, Bartsch N (2009). Decay dynamic of coarse and fine woody debris of a beech ( $\mathrm{Fa}$ gus sylvatica L.) forest in Central Germany. European Journal of Forest Research 128: 287296. - doi: 10.1007/s10342-009-0264-8

Nagel TA, Diaci J (2006). Intermediate wind disturbance in an old-growth beech-fir forest in southeastern Slovenia. Canadian Journal of Forest Research 36: 629-638. - doi: 10.1139/x05263

Gobierno de Navarra (2000). Plan forestal de Navarra [Forest management plan of Navarre]. Publicaciones del Gobierno de Navarra, Pamplona, Spain, pp. 466. [in Spanish]

O'Hara K, Gersonde R (2004). Stocking control concepts in uneven-aged silviculture. Forestry 77: 131-143. - doi: 10.1093/forestry/77.2.131

Oliva J, Colinas C (2007). Decline of silver fir (Abies alba Mill.) stands in the Spanish Pyrenees: role of management, historic dynamics and pathogens. Forest Ecology and Management 252: 84-97. - doi: 10.1016/j.foreco.2007.06. 017

Paillet $\mathrm{Y}$, Pernot C, Boulanger $\mathrm{V}$, Debaive N, Fuhr $\mathrm{M}$, Gilg O, Gosselin F (2015). Quantifying the recovery of old-growth attributes in forest reserves: a first reference for France. Forest Ecology and Management 346: 51-64. - doi: 10.1016/ j.foreco.2015.02.037

Pinto PE, Gégout JC, Hervé JC, Dhôte JF (2008). Respective importance of ecological conditions and stand composition on Abies alba Mill. dominant height growth. Forest Ecology and Management 255: 619-629. - doi: 10.1016/j.foreco. 2007.09.031

Piovesan G, Di Filippo A, Alessandrini A, Biondi F, Schirone B (2005). Structure, dynamics and dendroecology of an old-growth Fagus forest in the Apennines. Journal of Vegetation Science 16: 13-28. - doi: 10.1111/j.1654-1103.2005.tbo233 4. $\mathrm{x}$

Pretzsch H (1997). Analysis and modelling of spatial stand structures. Methodological considerations based on mixed beech-larch stands in Lower Saxony. Forest Ecology and Management 97: 237-253. - doi: 10.1016/S0378-1127(97) 00069-8

Rivas-Martínez S (2007). Mapa de series, geoseries y geopermaseries de vegetación de España. Memoria del mapa de vegetación potencial de España. Parte I [Map of series, geoseries and geopermaseries of the vegetation in Spain. Report of the potential vegetation map of Spain. Part I]. Itinera Geobotanica 7: 5-436. [in Spanish]

Rivas-Martínez S, Báscones JC, Díaz TE, Fernández-González F, Loidi J (1991). Vegetación del Pirineo Occidental [Vegetation of the western Pyrenees]. Itinera Geobotanica 5: 5-456. [in Spanish]

Rubin BD, Manion PD, Faber-Langendoen D (2006). Diameter distributions and structural sustainability in forests. Forest Ecology and Management 222: 427-438. - doi: 10.1016/j.for eco.2005.10.049

Rugani T, Diaci J, Hladnik D (2013). Gap dynamics and structure of two old-growth beech forest remnants in Slovenia. PloS ONE 8: e52641. - doi: 10.1371/journal.pone.0052641

Sangüesa-Barreda G, Camarero JJ, Oliva J, Montes F, Gazol A (2015). Past logging, drought and pathogens interact and contribute to forest dieback. Agricultural and Forest Meteorology 208: 85-94. - doi: 10.1016/j.agrformet.2015.04. 011

Schütz JP, Saniga M, Diaci J, Vrška T (2016). Comparing close-to-nature silviculture with processes in pristine forests: lessons from Central Europe. Annals of Forest Science 73: 911-921. doi: 10.1007/s13595-016-0579-9

Schwartz J, Nagel L, Webster C (2005). Effects of uneven-aged management on diameter distribution and species composition of northern hardwoods in Upper Michigan. Forest Ecology and Management 211: 356-370. - doi: 10.1016/j. foreco.2005.02.054

Silver EJ, D’Amato AW, Fraver S, Palik BJ, Bradford JB (2013). Structure and development of old-growth, unmanaged second-growth, and extended rotation Pinus resinosa forests in Minnesota, USA. Forest Ecology and Management 
291: 110-118. - doi: 10.1016/j.foreco.2012.11.033 Sitzia T, Trentanovi G, Dainese M, Gobbo G, Lingua $E$, Sommacal $M$ (2012). Stand structure and plant species diversity in managed and abandoned silver fir mature woodlands. Forest Ecology and Management 270: 232-238. - doi: 10.1016/j.foreco.2012.01.032

Townsend CR, Begon M, Harper JL (2003). Essentials of ecology. Blackwell Science, Boston, USA, pp. 530.

Westphal C, Tremer N, Von Oheimb G, Hansen J, Von Gadow K, Härdtle W (2006). Is the reverse
J-shaped diameter distribution universally applicable in European virgin beech forests? Forest Ecology and Management 223: 75-83. - doi: 10.1016/j.foreco.2005.10.057

Yamamoto SI (2000). Forest gap dynamics and tree regeneration. Journal of Forest Research 5: 223-229. - doi: 10.1007/BF02767114

Zenner E, Hibbs D (2000). A new method for modeling the heterogeneity of forest structure. Forest Ecology and Management 129: 7587. - doi: 10.1016/S0378-1127(99)00140-1

\section{Supplementary Material}

Tab. S1 - Characteristics of the sampled stands in the silver fir-beech forests from the western Pyrenees.

Appendix 1 - Protocol for the light regime measurement and analysis.

Link: Horvat_2720@supploo1.pdf 